University of Nebraska - Lincoln

DigitalCommons@University of Nebraska - Lincoln

\title{
Insect Infestation of Farm-Stored Maize in South Carolina: Towards Characterization of a Habitat
}

\author{
R. T. Arbogast
}

USDA-ARS

James E. Throne

USDA-ARS, Manhattan, KS, james.throne@ars.usda.gov

Arbogast, R. T. and Throne, James E., "Insect Infestation of Farm-Stored Maize in South Carolina: Towards Characterization of a Habitat" (1997). Publications from USDA-ARS / UNL Faculty. 2065.

https://digitalcommons.unl.edu/usdaarsfacpub/2065

This Article is brought to you for free and open access by the U.S. Department of Agriculture: Agricultural Research Service, Lincoln, Nebraska at DigitalCommons@University of Nebraska - Lincoln. It has been accepted for inclusion in Publications from USDA-ARS / UNL Faculty by an authorized administrator of DigitalCommons@University of Nebraska - Lincoln. 


\title{
Insect Infestation of Farm-Stored Maize in South Carolina: Towards Characterization of a Habitat
}

\author{
R. T. ARBOGAST, ${ }^{*}$ and J. E. THRONE ${ }^{2}$
}

${ }^{\prime}$ Center for Medical, Agricultural and Veterinary Entomology, ARS, USDA, P.O. Box 14565, Gainesville, FL 32604, U.S.A. and ${ }^{2}$ Grain Marketing and Production

Research Center, ARS, USDA, 1515 College Ave., Manhattan, KS 66502, U.S.A.

(Accepted 28 February 1997)

\begin{abstract}
Protecting stored grain from insect damage, with minimum pesticide risk, will require pest management based on comprehensive understanding of storage environments and their interactions with pest populations. Computer modeling offers the means to this understanding. To obtain data sets for modeling selected pests of stored maize, we studied maize storages on six farms in a four-county area of southwestern South Carolina. Grain moisture content was measured monthly, and grain temperatures were recorded hourly for one storage season. Insect populations were monitored by taking grain and pitfall trap samples at weekly or monthly intervals. Hourly mean grain temperatures remained below optimal levels for growth and development of insects during most of the storage period. Grain moisture content varied from 11.2 to $16.4 \%$. Forty three species of insects and one species complex, representing 26 families in four orders, were detected. The estimated importance of each species in the farm storage habitat, as measured by relative abundance and frequency of occurrence, depended on whether grain sampling or trapping was used. With trapping, Cryptolestes species (mostly $C$. pusillus (Schönherr)), the Carpophilus dimidiatus complex ( $C$. dimidiatus (F.), $C$. freemani Dobson and C. mutilatus Erichson), Sitophilus species (mostly S. zeamais Motschulsky), Xylocoris flavipes (Reuter) and Oryzaephilus surinamensis (L.) appeared most important. With grain sampling, $S$. zeamais, Sitotroga cerealella (Olivier) and $C$. pusillus appeared most important. Insects were most abundant (or active) in the fall and again in the spring, if storage extended that long. Grain samples indicated more insects near the grain surface, but traps sometimes detected more near the bottom of the bulk. (C) 1997 Elsevier Science Ltd
\end{abstract}

Key words-maize, corn, farm storage, species composition, storage habitat

\section{INTRODUCTION}

The environmental risks associated with chemical pesticides, and increasing resistance among target pests, will force greater dependence on integrated systems that employ alternative control methods. Successful application of these systems to protect stored grain will require comprehensive understanding of storage environments and their interactions with pest populations. The concept of grain storages as complete ecosystems (Sinha, 1973, 1995; Calderon, 1981) provides a framework on which to build the required understanding, and computer modeling provides the necessary tools.

Stored-grain ecosystems are created and controlled by man. Their energy reserve, held entirely within the harvested grain, is non-renewable. They are immature, unstable systems subject to frequent cataclysms through human intervention. Their biotic component consists of the grain with

*Author to whom all correspondence should be addressed. 
its associated flora and fauna. Their abiotic component includes temperature, moisture, gases, pesticides, the storage structure and so on.

Computer models, by simulating pest population dynamics, offer means of predicting the extent of damage to be expected and guidance in deciding the timing and nature of control measures (Calderon, 1981). However, development and validation of computer models require extensive data sets representing the spatial and temporal dynamics of the systems being modeled. An adequate data set must include all key variables, both biotic and abiotic, that affect insect population growth. For the purposes of modeling, such a data set for a particular storage habitat can be regarded as a characterization of the habitat. A characterization provides sufficient information to drive a model and produce an accurate simulation of population growth.

Throne (1995) emphasized the need to characterize the grain marketing system from farm through processing so that we know which biotic and abiotic factors influence grain storage. He pointed out that any model must include at least grain temperature and moisture content to describe insect population growth accurately in a real storage situation and noted the limited availability of historical data sets that can be used to run simulations. Other factors may be added as necessary in the process of validation, revision and revalidation. Likely candidates would include species composition, rates of immigration and emigration, condition of grain, and prevalence of disease.

Data sets adequate to support the modeling process are scarce, especially for grain storages in the southeastern U.S., where the warm, humid climate creates the potential for serious insect problems throughout the storage period (U.S. Department of Agriculture, 1991). The present paper reports a study of maize storages on farms in South Carolina that was done to support our efforts in modeling the population dynamics of selected insect pests. The study generated extensive data sets for insect populations and grain temperature, as well as a more limited data set for grain moisture content. The data sets are used here to illustrate certain characteristics of this storage environment, specifically: (1) spatial and seasonal variation in grain temperature, (2) frequency distribution of mean hourly grain temperatures, (3) range of grain moisture content, (4) spatial and seasonal variation in numbers of insects, and (5) relative abundance and frequency of occurrence of insect species (or species groups).

\section{MATERIALS AND METHODS}

We studied insect populations in maize stored on six farms in southwestern South Carolina (Aiken, Bamberg, Barnwell, and Hampton Counties). Shelled maize was harvested during August and September and stored in steel bins ranging in capacity from 85 to $460 \mathrm{t}$. The largest of these bins was $10.7 \mathrm{~m}$, and the smallest, $5.5 \mathrm{~m}$ in diameter. All were equipped with perforated false floors and fans for aeration. Control measures varied and included application of $1 \%$ malathion dust in wheat flour as the grain was augered into the bins, fumigation with phosphine at completion of loading, and aeration during cool weather. The storage period ranged from 3 to 9 months.

\section{Grain temperature and moisture content}

We measured and recorded grain temperature by means of two-channel temperature recorders

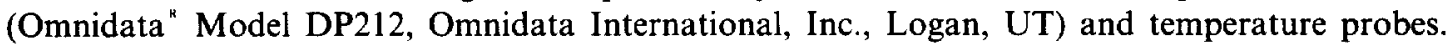
Readings were taken at four points $(0.3$ and $1.8 \mathrm{~m}$ below the grain surface at the bin center and south of the center, $0.9 \mathrm{~m}$ from the wall) every $5 \mathrm{~min}$, and hourly averages were recorded. At monthly intervals, we took one 0.51 sample of maize from the grain surface near the center of each bin and held it in a sealed polypropylene jar for determination of moisture content (within 24-48 h) with a digital moisture computer (Burrows" Model 700, Seedboro Equipment Co., Chicago, IL).

\section{Grain sampling and insect trapping}

For the purposes of sampling, we divided the grain bulk conceptually into eight strata of equal area at each of three levels in the bin, one just below the grain surface, one just above the false floor, and one midway between. The cross-sectional area of the bin at each level was first divided into quadrants centered on the cardinal points of the compass and then divided equally into an inner circle and outer annulus. Pitfall traps, perforated grain probe traps (Burkholder, 1984) 
without lures, provided relative estimates of insect populations, and grain samples taken with $255 \mathrm{ml}$ deep-bin cups provided absolute estimates.

We studied three of the bins more intensively than the others. Bins 1 and 2 were located on two farms in Hampton County and Bin 3 on a farm in Bamberg County. Bin 1 was $7.3 \mathrm{~m}$ in diameter by $6.1 \mathrm{~m}$ high and had a capacity of about $175 \mathrm{t}$. No treatment was applied other than infrequent aeration during cool weather. Bins 2 and 3 were $5.5 \mathrm{~m}$ in diameter by $5.5 \mathrm{~m}$ high, each with a capacity of about $85 \mathrm{t}$. In both, malathion was applied to the grain during loading, and both were occasionally aerated during cool weather. We took bin-cup and trap samples from these bins and made measurements of temperature and moisture content. Bin-cup samples were taken at monthly intervals. Each consisted of 24 subsamples, one from each of the 24 strata. In the remaining three bins, we took only bin-cup samples and measured moisture content, and in these bins, each bin-cup sample consisted of five subsamples taken from the surface, one from the outer portion of each quadrant and one near the center of the bin. The grain from each subsample was transferred from the cup to a 0.51 polypropylene jar, which was then capped with filter paper over wire mesh and held in the laboratory at $30^{\circ} \mathrm{C}$ and $60 \%$ r.h. Grain samples were sieved and adult insects counted within a day after sampling and then weekly for 4 weeks. Totals of these five counts were used in all calculations. A trap sample consisted of captures from eight traps set for 1 week just below the grain surface, one in each stratum. Beginning in December, each trap sample also included captures from four traps set at the bottom of the bin, one in each inner stratum. The middle level was not sampled with traps. Initially, we set and retrieved traps at weekly intervals, but later changed to monthly intervals. Traps were then set 1 week before the sampling date and removed when the bin-cup samples were taken. Each trap was emptied directly into a vial of alcohol, and the preserved insect samples were stored until they could be processed in the laboratory.

\section{Identification of insects}

With the exception of a species of Corylophidae (minute fungus beetles), all insects captured were identified to genus, and most were identified to species. Specimens of Sitophilus, and initially specimens of Cryptolestes, were identified to species by dissection and examination of the genitalia (Lefkovitch, 1959; Halstead, 1963). However, some trap catches of these genera were so large that it was impractical to examine every specimen in this manner. For this reason, we lumped the two species of each genus together, but in most cases, saved a sample of the specimens for later examination. The samples of Sitophilus were subsequently determined by dissection and those of Cryptolestes by a method discovered during the present study (Arbogast, 1991). Counts of these samples were then used to estimate the proportion of each species in the complete trap catch of the genus (Scheaffer et al., 1986). Three members of the Carpophilus dimidiatus complex (Table 1) are very common in maize fields in South Carolina (Bartelt et al., 1995) and occur in storages as well (Weaver, Bartelt and Arbogast, unpublished). Members of this complex were not sorted to species.

\section{Relative abundance and frequency of occurrence}

We pooled the data for all farms and all sample dates to estimate the frequency of occurrence and relative abundance of each species, using statistical methods given by Scheaffer $e t$ al. (1986). The frequency of occurrence of a species is the percentage of all possible samples (or bin-days) in which the species occurs; it is estimated as the percentage of samples actually taken in which the species is found. The relative abundance of a species is the percentage of the insect population represented by the species; it is estimated as the percentage of the species in the total number of insects collected. For bin-cup samples, we defined a bin-day as storage of maize in one bin for one day and treated our pooled data as a simple random sample of $n=38$ selected to estimate the percentage of $N$ (total bin-days for the four-county area of our study during the 1985-1986 storage season) in which each species occurred. We treated our pooled trap catches in the same manner with $n=27$ and $N=$ total bin-weeks. Estimation of relative abundance was similar, but with $n=$ number of insects collected (1622 in bin cups and 14996 in traps) and $N=$ total number of insects in the bins sampled. 
Table 1. Insects found in maize storages on six South Carolina farms during the 1985-1986 storage season

\begin{tabular}{|c|c|c|c|}
\hline Taxon & Abbreviation & Taxon & Abbreviation \\
\hline Hemiptera & & Tenebrionidae & \\
\hline Anthocoridae & & Tribolium castaneum (Herbst) & TC \\
\hline Xylocoris flavipes (Reuter) & $\mathrm{XF}$ & Palorus subdepressus (Wollaston) & PS \\
\hline Xylocoris galactinus (Fieber) & $\mathrm{XG}$ & Mycetophagidae & \\
\hline Coleoptera & & Typhaea stercorea (L.) & TS \\
\hline Carabidae & & Litargus balteatus LeConte & LB \\
\hline Tachys sp. & TACH & Anthicidae & \\
\hline Staphylinidae & & Anthicus floralis (L.) & AFLOR \\
\hline Myrmecocephalis concinnus (Erichson) & MC & Bruchidae & \\
\hline Atheta coriaria (Kraatz) & $\mathrm{ACO}$ & Megacerus cubiculus (Casey) & $\mathrm{MCU}$ \\
\hline Histeridae & & Anthribidae & \\
\hline Carcinops pumilio (Erichson) & CPUM & Araecerus fasciculatus (De Geer) & $\mathbf{A F}$ \\
\hline Dermestidae & & Curculionidae & \\
\hline Trogoderma inclusum (LeConte) & TI & Sitophilus oryzae (L.) & SO \\
\hline Anobiidae & & Sitophilus zeamais Motschulsky & SZ \\
\hline Stegobium paniceum (L.) & SP & Hymenoptera & \\
\hline Trogositidae & & Braconidae & \\
\hline Tenebroides mauritanicus (L.) & TM & Bracon hebetor Say & BH \\
\hline Nitidulidae & & Ichneumonidae & \\
\hline Conotelus stenoides Murray & CS & Venturia canescens (Gravenhorst) & VC \\
\hline Carpophilus dimidiatus complex: & $\mathrm{CD}$ & Pteromalidae & \\
\hline C. dimidiatus $(\mathbf{F})$. & & Anisopteromalus calandrae (Howard) & $\mathrm{AC}$ \\
\hline C. freemani Dobson & & Choetospila elegans Westwood & $\mathrm{CE}$ \\
\hline C. mutilatus Erichson & & Pteromalus cerealellae (Ashmead) & PC \\
\hline Carpophilus hemipterus (L.) & CHEM & Chalcididae & \\
\hline Carpophilus humeralis (F.) & CHUM & Haltichella onatas (Walker) & HO \\
\hline Cucujidae & & Bethylidae & \\
\hline Oryzaephilus surinamensis (L.) & OS & Cephalonomia tarsalis (Ashmead) & CT \\
\hline Silvanoprus scuticollis (Walker) & $\mathrm{SSCU}$ & Cephalonomia waterstoni Gahan & CW \\
\hline Ahasverus advena (Waltl) & AA & Holepyris sylvanidis Brethés & HS \\
\hline Cathartus quadricollis & & Lepidoptera & \\
\hline (Guérin-Méneville) & $\mathrm{CQ}$ & Cosmopterigidae & \\
\hline Cryptolestes ferrugineus (Stephens) & $\mathrm{CF}$ & Pyroderces rileyi (Walsingham) & $\mathbf{P R}$ \\
\hline Cryptolestes pusillus (Schönherr) & CP & Gelechiidae & \\
\hline Cryptophagidae & & Sitotroga cerealella (Olivier) & SC \\
\hline Cryptophagus cellaris (Scopoli) & CCEL & Pyralidae & \\
\hline Languriidae & & Cadra cautella (Walker) & $\mathrm{CC}$ \\
\hline Cryptophilus integer (Heer) & $\mathrm{CI}$ & Plodia interpunctella (Hübner) & PI \\
\hline Corylophidae & CORYL & & \\
\hline
\end{tabular}

\section{RESULTS}

\section{Grain temperature}

Seasonal changes in mean grain temperature reflect the combined effects of weather, aeration and the metabolic processes of grain, arthropods and microflora (Fig. 1). Temperatures recorded in Bin 1 ranged from $5.5^{\circ} \mathrm{C}$, following aeration in early December, to $36.0^{\circ} \mathrm{C}$ in late May. The November maximum of $33.5^{\circ} \mathrm{C}$ was associated with a small hot spot near the center of the bin, apparently caused by a leak in the roof. The maximum temperature in $\operatorname{Bin} 2\left(46.5^{\circ} \mathrm{C}\right)$ was associated with a much larger hot spot, and the minimum $\left(5.5^{\circ} \mathrm{C}\right)$ was recorded immediately after aeration was performed to eliminate the hot spot. There was no heating of the grain in Bin 3. Temperatures ranged from a low of $3.0^{\circ} \mathrm{C}$ in early February to $26.5^{\circ} \mathrm{C}$ in April, just before the grain was removed. In the absence of grain heating, temperatures near the south sides of the bins were much the same at 0.3 and $1.8 \mathrm{~m}$. The same was true of the center during the fall and winter, but in the spring, the surface warmed more rapidly and reached much higher temperatures than the underlying layers. It is interesting to note that, even with the occurrence of hot spots, grain temperatures remained below optimal levels for growth and development of insects during most of the storage period in all three bins; more than 55\% of the hourly temperatures recorded in Bins 1 and 2, and more than $85 \%$ of those recorded in Bin 3, were $20^{\circ} \mathrm{C}$ or less (Table 2). We have observed this same sort of temperature distribution in other years and on other farms in South Carolina (R.T.A. and J.E.T., unpublished data), and its significance for population modeling was discussed by Weaver and Throne (1994). 

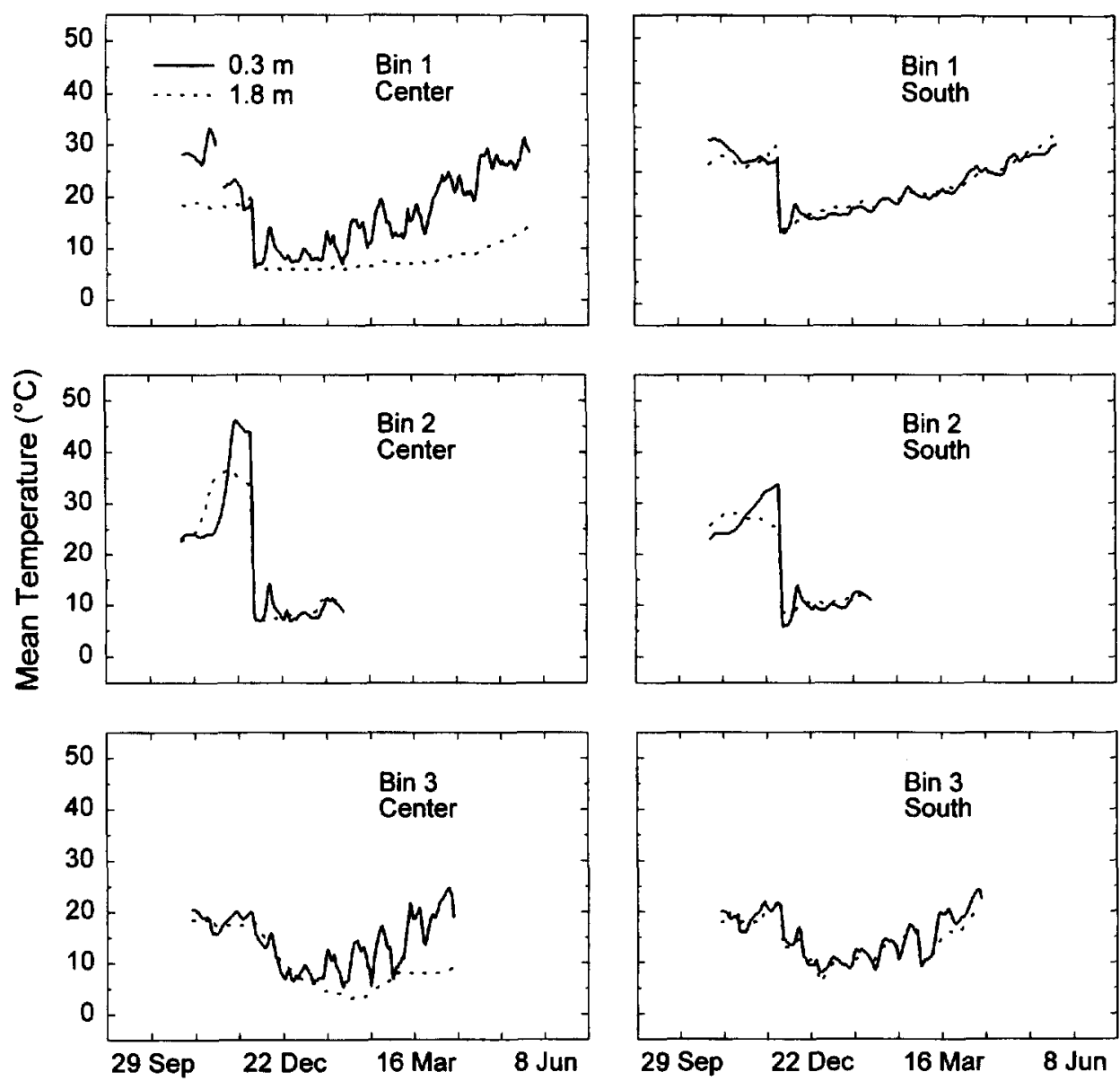

Fig. 1. Seasonal variation in mean daily temperature at four points in maize storages on three South Carolina farms during 1985-1986.

\section{Grain moisture content}

The moisture content of the maize ranged from 11.2 to $15.1 \%$ when it was placed in storage. In Bin 1, moisture content declined from 14.2 to $11.3 \%$ during storage, and in Bin 3, it declined from 14.5 to $12.1 \%$. Moisture content in Bin 2 increased to a maximum of $16.4 \%$ in November and never fell below $15.1 \%$.

\section{Insect species detected}

Grain sampling and trapping together detected a total of 43 species and one species complex, representing 26 families in four orders (Table 1). Of these, 24 species were detected by sampling and 40 by trapping. Of the four species not captured in traps, three were detected in bins in which traps were not used. The size of the fourth, Araecerus fasciculatus (De Geer), may have prevented it from entering the traps. Most of the species recorded are of common occurrence in stored products, but a few are unusual enough to merit special comment. Three specimens of Silvanopris scuticollis (Walker) were collected from Bin 2 during November when the grain was heating. This tropicopolitan species has been recorded previously from stored products as well as other habitats, such as humus and rotting leaves (Halstead, 1993). A single specimen of Haltichella onatas (Walker) was collected in the same bin during October and was probably associated with a field infestation of the pink scavenger caterpillar, Pyroderces rileyi (Walsingham), one of its hosts (Halstead, 1990). The pink scavenger caterpillar commonly infests maize in the southern states, both in the field and in storage (U.S. Department of Agriculture, 1986), but does not survive well on shelled maize. The single specimens of Tachys sp. and Megacerus cubiculus (Casey), and two specimens of Corylophidae, again from the same bin, were probably incidental invaders. 
Table 2. Distribution of mean hourly temperatures at four points in maize storages on South Carolina farms

\begin{tabular}{|c|c|c|c|c|c|c|c|c|c|c|c|}
\hline \multirow[b]{2}{*}{ Location and date } & \multicolumn{10}{|c|}{ Percentage frequency of hours at temperatures $\left({ }^{\circ} \mathrm{C}\right)$} & \multirow[b]{2}{*}{ Total hours* } \\
\hline & $0.1-5.0$ & $5.1-10.0$ & $10.1-15.0$ & $15.1-20.0$ & $20.1-25.0$ & $25.1-30.0$ & $30.1-35.0$ & $35.1-40.0$ & $40.1-45.0$ & Above 45.0 & \\
\hline \multicolumn{12}{|c|}{$\begin{array}{l}\text { Bin } 1 \\
19 \text { Oct } 1985-29 \text { May } 1986\end{array}$} \\
\hline \multicolumn{12}{|c|}{ Center } \\
\hline $0.3 \mathrm{~m}$ deep & 0.0 & 21.8 & 19.3 & 16.4 & $\begin{array}{r}17.4 \\
0.2\end{array}$ & $\begin{array}{r}18.4 \\
0.0\end{array}$ & $\begin{array}{l}4.4 \\
0.0\end{array}$ & $\begin{array}{l}0.1 \\
0.0\end{array}$ & $\begin{array}{l}0.0 \\
0.0\end{array}$ & $\begin{array}{l}0.0 \\
0.0\end{array}$ & $\begin{array}{l}5325 \\
5325\end{array}$ \\
\hline $\begin{array}{l}1.8 \mathrm{~m} \text { deep } \\
\text { South quadrant }\end{array}$ & 0.0 & \multirow{2}{*}{\multicolumn{6}{|c|}{ South quadrant }} & & & & \\
\hline $\begin{array}{l}\text { South quadrant } \\
0.3 \mathrm{~m} \text { deep }\end{array}$ & 0.0 & & & & & 7.3 & 0.0 & 0.0 & 0.0 & 0.0 & 5325 \\
\hline $1.8 \mathrm{~m}$ deep & 0.0 & 7.8 & 33.4 & 22.5 & 28.4 & 7.9 & 0.0 & 0.0 & 0.0 & 0.0 & 5325 \\
\hline \multirow{2}{*}{\multicolumn{12}{|c|}{$\begin{array}{l}\text { Bin } 2 \\
19 \text { Oct } 1985-30 \text { Jan } 1986\end{array}$}} \\
\hline & & & & & & & & & & & \\
\hline \multicolumn{11}{|c|}{ Center } & 2471 \\
\hline $0.3 \mathrm{~m}$ deep & $<0.1$ & 44.1 & 11.8 & 0.2 & $\begin{array}{l}21.7 \\
100\end{array}$ & $\begin{array}{l}4.6 \\
5.9\end{array}$ & $\begin{array}{r}2.6 \\
163\end{array}$ & $\begin{array}{r}1.9 \\
11.5\end{array}$ & $\begin{array}{l}9.2 \\
0.0\end{array}$ & $\begin{array}{l}4.0 \\
0.0\end{array}$ & 2471 \\
\hline $\begin{array}{l}1.8 \mathrm{~m} \text { deep } \\
\text { South quadrant }\end{array}$ & 0.0 & 41.0 & 15.1 & 0.1 & 10.0 & 3.9 & 16.5 & & & & \\
\hline \multicolumn{3}{|l|}{ South quadrant } & 22.3 & 0.1 & 17.1 & 13.1 & 13.6 & 0.0 & 0.0 & 0.0 & 2471 \\
\hline $1.8 \mathrm{~m}$ deep & 0.0 & 17.5 & 38.7 & 0.1 & 0.2 & 43.6 & 0.0 & 0.0 & 0.0 & 0.0 & 2471 \\
\hline \multirow{2}{*}{\multicolumn{12}{|c|}{$\begin{array}{l}\text { Bin } 3 \\
25 \text { Oct } 1985-10 \text { April } 1986\end{array}$}} \\
\hline & & & & & & & & & & & \\
\hline \multicolumn{12}{|c|}{ Center } \\
\hline $0.3 \mathrm{~m}$ deep & 0.6 & 30.2 & 23.7 & 35.0 & 9.6 & 0.9 & 0.0 & 0.0 & 0.0 & 0.0 & 4020 \\
\hline $1.8 \mathrm{~m}$ deep & 22.0 & 44.6 & 6.1 & 27.2 & 0.0 & 0.0 & 0.0 & 0.0 & 0.0 & 0.0 & 4020 \\
\hline \multicolumn{12}{|l|}{ South quadrant } \\
\hline $0.3 \mathrm{~m}$ deep & 0.0 & 18.5 & 33.0 & 34.9 & 13.5 & 0.0 & 0.0 & 0.0 & 0.0 & 0.0 & 4020 \\
\hline $1.8 \mathrm{~m}$ deep & 0.0 & 18.6 & 39.0 & 32.9 & 9.3 & 0.0 & 0.0 & 0.0 & 0.0 & 0.0 & 4020 \\
\hline
\end{tabular}

*Including hours with missing values. 


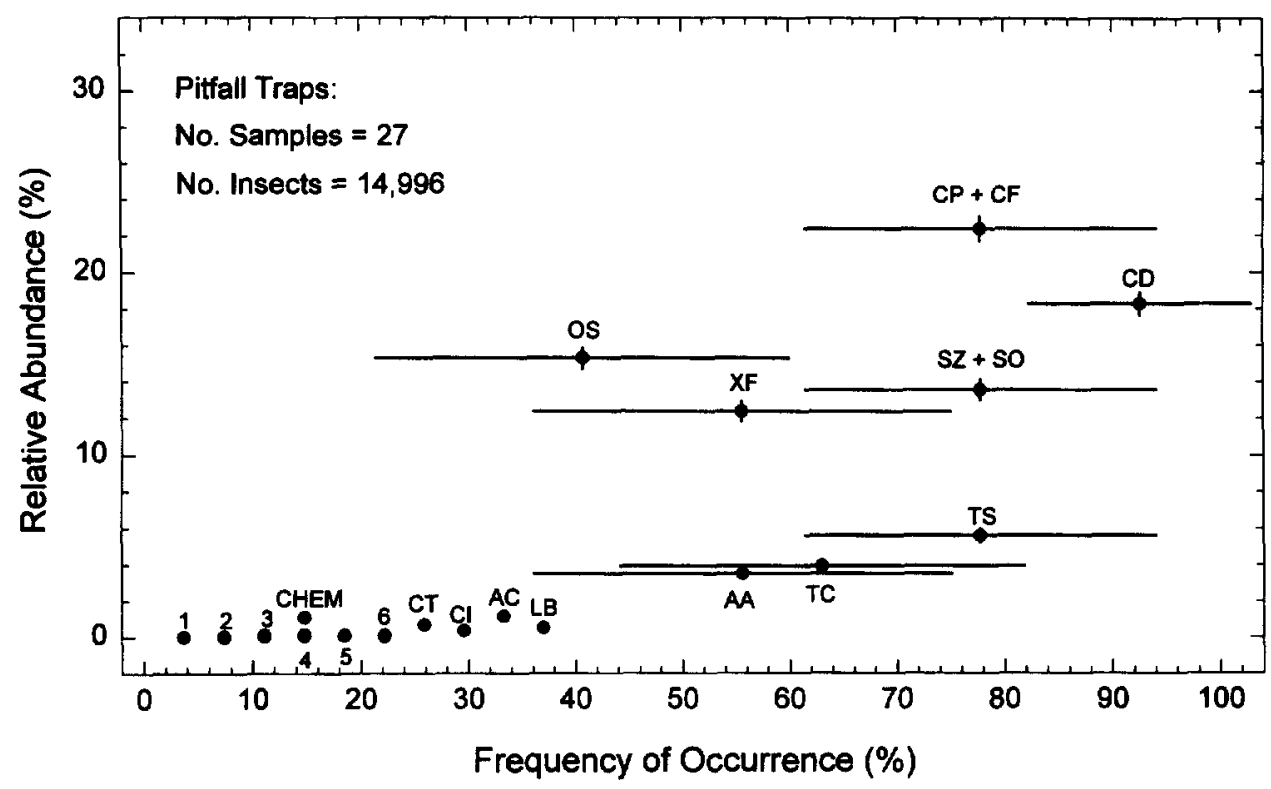

Fig. 2. Percentage occurrence in bin samples and relative abundance of insect species estimated from pitfall trap captures. See Table 1 for abbreviations of species. $1=\mathrm{CC}, \mathrm{CHUM}, \mathrm{CPUM}, \mathrm{CS}, \mathrm{HO}$, MCU, SSCU, TACH, TM; $2=$ AFLOR, CCEL, CORYL, MC, PI, PS; $3=\mathrm{BH}, \mathrm{CW} ; 4=\mathrm{ACO}$, CHEM, HS, XG; $5=\mathrm{CQ}$, SP; $6=\mathrm{CE}, \mathrm{SC}$. Error bars represent \pm 2 standard deviations and, for the sake of clarity, are omitted from points clustered in the lower left of the graph. Errors associated with these points ranged from \pm 0.01 to 0.18 for relative abundance and from \pm 7.4 to 18.9 for occurrence.

\section{Relative abundance and frequency of occurrence}

Together, the abundance of a species relative to the total insect population and its frequency of occurrence provide a measure of its importance in this particular storage ecosystem. The plots of relative abundance against frequency of occurrence in Figs 2 and 3 illustrate the status of various

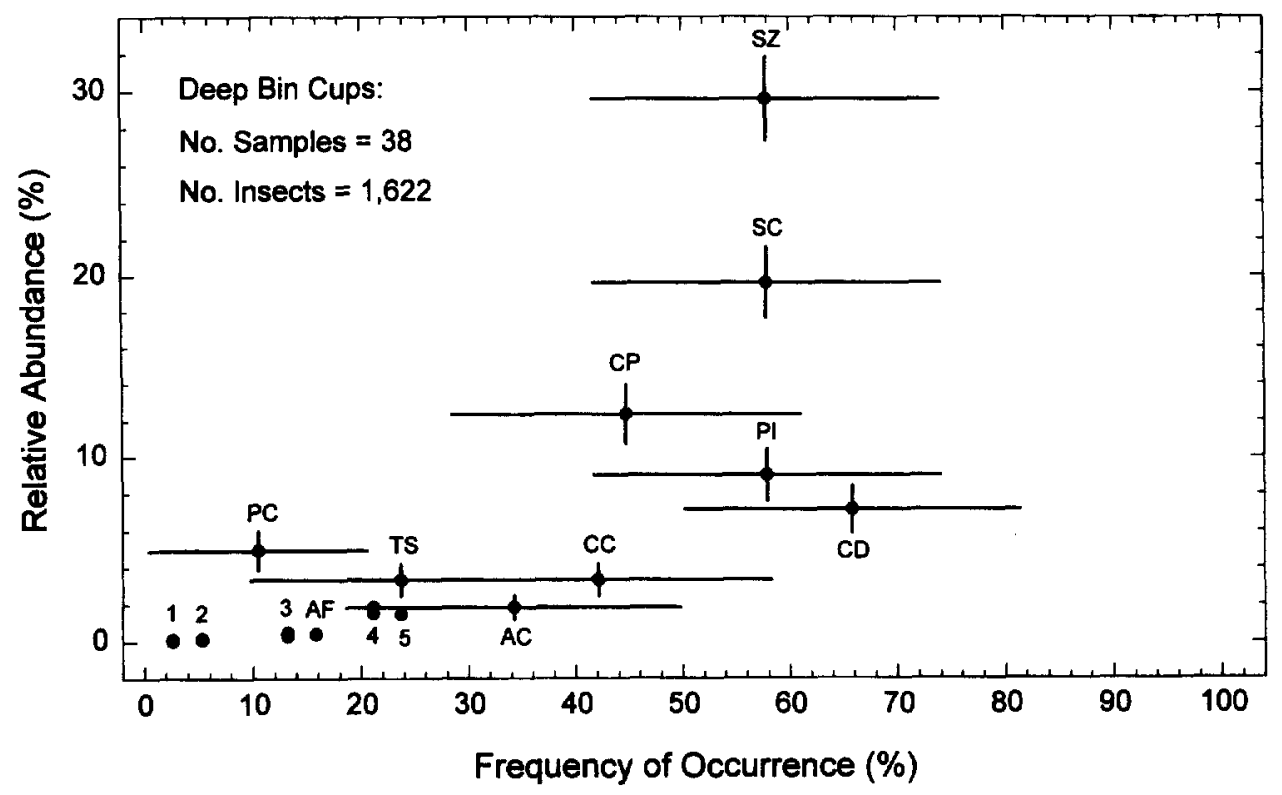

Fig. 3. Percentage occurrence in bin samples and relative abundance of insect species estimated from grain samples. See Table 1 for abbreviations of species. $1=\mathrm{CI}, \mathrm{XG}, \mathrm{PR}, \mathrm{VC} ; 2=\mathrm{CE}, \mathrm{CW}, \mathrm{OS} ; 3=\mathrm{LB}$, SO, AA; $4=\mathrm{CF}, \mathrm{BH} ; 5=\mathrm{TC}, \mathrm{XF}$. Error bars represent \pm 2 standard deviations and, for the sake of clarity, are omitted from points clustered in the lower left of the graph. Errors associated with these points ranged from \pm 0.12 to 0.67 for relative abundance and from \pm 5.3 to 14.0 for occurrence. 


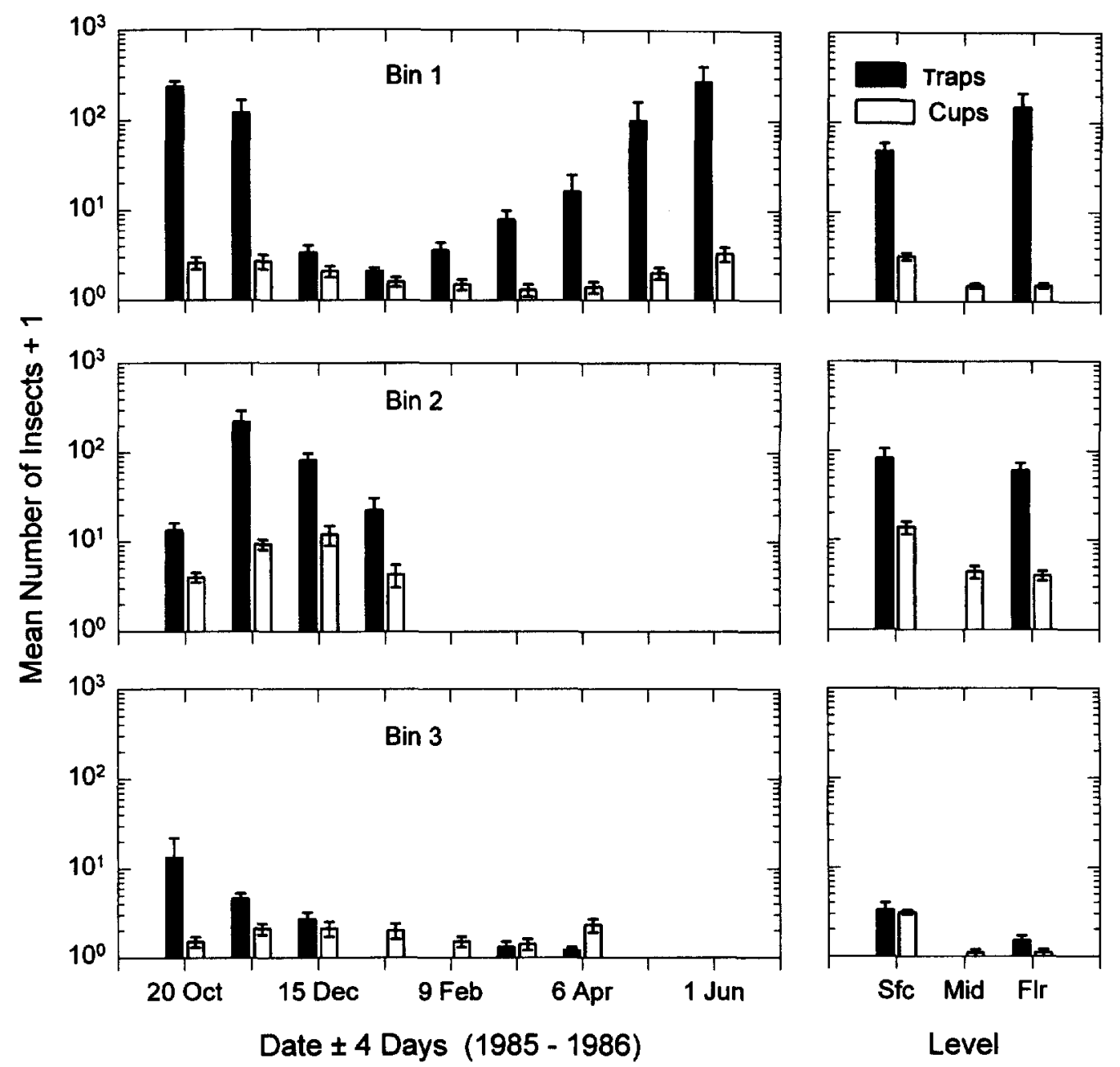

Fig. 4. Seasonal and vertical distribution of insects (all species) captured in pitfall traps or taken in grain samples from three bins. For seasonal distribution, all layers were pooled and for vertical distribution, all sample dates were pooled. Error bars represent standard errors of means.

species as estimated by grain sampling and trapping. The precision of estimation is much greater for relative abundance than for frequency of occurrence because of the larger sample size $(n)$. Not wunexpectedly, the two methods yield quite different results. With pitfall traps, Cryptolestes species-mostly C. pusillus (Schönherr), the Carpophilus dimidiatus complex, Sitophilus species-mostly S. zeamais Motschulsky, Xylocoris flavipes (Reuter) and Oryzaephilus surinamensis (L.) appeared most important. With grain samples, S. zeamais, Sitotroga cerealella (Olivier) and C. pusillus appeared most important. Any method used to estimate importance must give every species an equal chance of being counted. Although traps are generally more sensitive in detecting insects, the trap that we used was clearly biased against moths. Also, our field experience suggests that the importance of Plodia interpunctella (Hübner) may have been underestimated by both methods. Some carefully balanced combination of sampling and different trap types will probably be required to obtain a more accurate assessment of species composition.

\section{Seasonal and spatial variation}

When storage extended from fall to late spring or summer, traps indicated the greatest insect populations in the fall and spring (Bin 1) (Fig. 4). This pattern may represent true seasonal changes in population density, but it may reflect also seasonal changes in insect activity. Trap catch is a function of activity as well as population density, and activity is strongly influenced by temperature. However, bin-cup samples also gave at least a weak indication of the same seasonal pattern. The insect population in Bin 3 did not reach very high levels, and the grain was removed in April, but 
again, bin-cup samples gave at least some indication of the same pattern. In Bin 2, which was emptied at the end of January, the highest population levels coincided with development of the hot spot. In all three bins, grain sampling indicated more insects near the grain surface than near the bin floor or in the middle of the grain bulk. Estimates of vertical distribution obtained by trapping varied from bin to bin and were in agreement with sampling results only in Bin 3. Trap estimates may not present a true picture of average vertical distribution over the storage season, because trapping began later at the bin floor than at the surface, and we did not trap at all in the middle layer.

The grain stored in Bin 1 received no treatment other than occasional aeration during cool weather, and the insect population reached high levels early in the storage period. Furthermore, the grain was held in storage for more than 8 months (10 September 1985-29 May 1986), so this bin provided an opportunity to examine seasonal distribution of individual species. Trap samples of the six most abundant species (or species groups) were selected for examination (Fig. 5). All of these, except $X$. flavipes, contributed to an outbreak that occurred in the spring during the last 3 months of storage and involved the north and east quadrants near the bin floor. Clearly, the spring peak in the total insect population of the bin (Fig. 4) can be attributed largely to this outbreak, although the $C$. dimidiatus complex, $O$. surinamensis and Cryptolestes showed modest increases at the grain surface as well. Most of the Cryptolestes trapped during the period from October through December were $C$. pusillus $(88 \pm 5$ to $100 \pm 0 \%)$, but by May, less than half were C. pusillus $(40 \pm 12 \%)$. Xylocoris flavipes, was abundant at the surface in the fall, but had declined markedly by December and did not increase again as the grain warmed in the spring. Tribolium castaneum (Herbst) and Sitophilus had similar patterns, but were less abundant in the fall. Most, if not all, of the Sitophilus trapped at the grain surface were Sitophilus oryzae (L.) (three specimens were not identified to species), but most of those associated with the outbreak were $S$. zeamais. The estimated percentage of $S$. zeamais in trap catches of Sitophilus during May ranged from $93 \pm 4$ to $95 \pm 2$.
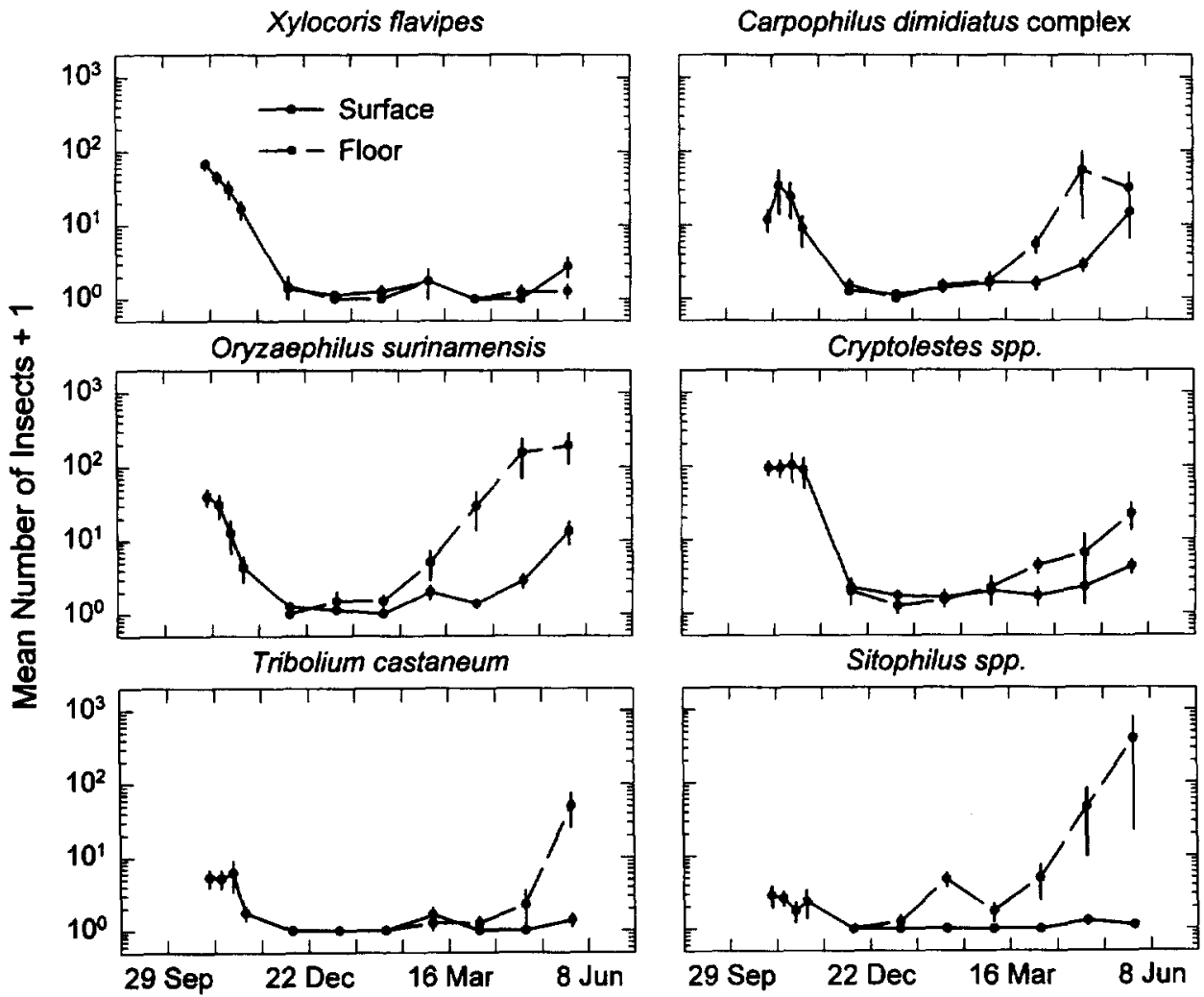

Fig. 5. Seasonal distribution of various insect species captured in pitfall traps at the grain surface and at the bin floor of Bin 1 during 1985-1986. Error bars represent standard errors of means. 

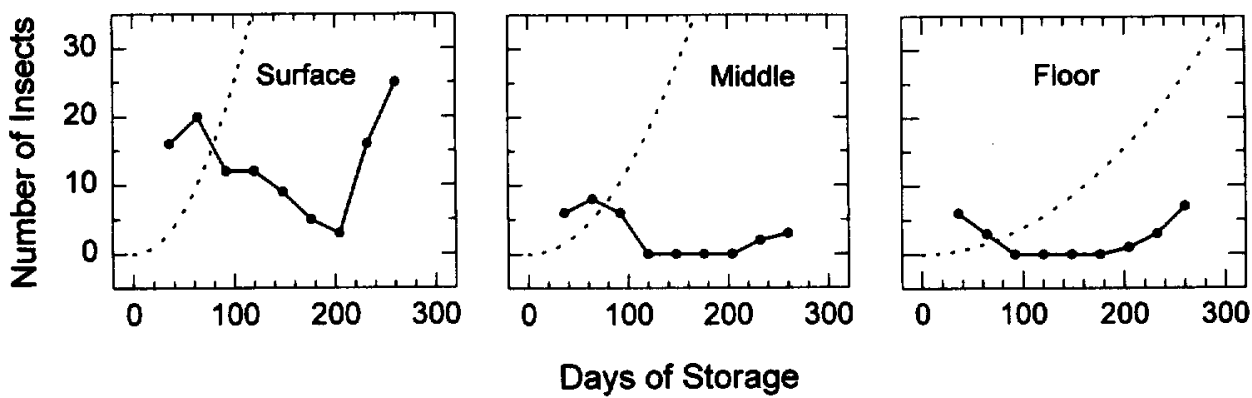

Fig. 6. Relationship between duration of storage and total number of Cryptolestes (pusillus + ferrugineus) in $255 \mathrm{ml}$ grain samples taken from three levels in Bin 1 . The dashed curves show numbers predicted by Hagstrum's (1989) model of vertical distribution.

\section{DISCUSSION}

Our findings differ somewhat from those of earlier studies, although there are many similarities. In a statewide survey of farm-stored grain and soybeans in South Carolina, Horton $(1981,1982)$ detected 29 species of stored-product insects in standard grain-probe samples of maize. He found $S$. zeamais, C.pusillus, $T$. castaneum and Carpophilus dimidiatus ( $\mathrm{F}$.) (or the $C$. dimidiatus complex) to be the most frequent species in maize storages on South Carolina farms. These species infested 56, 44, 42 and 38\%, respectively, of maize sampled. Oryzaephilus surinamensis, Typhaea stercorea (L.) and Rhyzopertha dominica (F.) infested 26-27\%. Eden (1967) found 17 species in a three-state survey of farm-stored maize. He reported that $S$. oryzae was by far the most abundant species in stored maize in Georgia, Alabama and Mississippi. However, he did not report the occurrence of $S$. zeamais and may have confused the two species. He further reported that after a year of storage, $T$. castaneum was the second most abundant species, with $C$. pusillus, Tenebroides mauritanicus (L.) and Cathartus quadricollis (Guérin-Méneville) being of lesser importance. In Alabama, $C$. dimidiatus and in Mississippi, S. cerealella were also important. Wong Corral et al. (1992) reported 25 species infesting farm storages of corn in northeastern Sonora, Mexico. Barak and Harein (1981) found Cryptolestes spp. to be the most frequently encountered insects in maize stored on farms in Minnesota, followed by Ahasverus advena (Waltl), $P$. interpunctella, Cynaeus angustus (LeConte), $T$. castaneum, $T$. stercorea and $O$. surinamensis, in order of frequency. Storey et al. (1982) listed 14 species (or species groups) found in U.S. maize loaded for export at port terminals in the United States and Canada. Sitophilus spp. and Cryptolestes spp. were found most frequently; $P$. interpunctella and Cadra cautella (Walker) were the most abundant.

Such variation among studies with respect to abundance and frequency of insect species is an expected consequence of diversity in the factors influencing infestation. Infestation of stored grain by insects can be visualized as a process of invasion, colonization and population growth-used in this sense, infestation is essentially synonymous with population dynamics. The initial species composition of a colonizing insect population depends upon the mix of species available at the time and place of storage, and is thus subject to chance, as well as climatic and other factors. Following initial colonization, species composition may undergo a succession of changes driven by species-specific responses to grain degradation, interactions among species, and arrival of new colonizers (Arbogast and Mullen, 1988).

There are basically three mechanisms by which insects invade and colonize stored grain: (1) infestation of standing crops in the field, followed by passive movement with harvested grain into storage; (2) dispersal from grain residues and other reservoirs within storage structures; and (3) immigration from reservoirs outside storage structures, such as unharvested grain, grain residues and other plant debris and nests of birds, rodents, bees, and wasps (Linsley, 1944). Identifying reservoirs and mechanisms of infestation and quantifying the contribution of each are essential steps in modeling pest population dynamics. Small relict populations, that are able to survive under adverse conditions or in locally favorable situations such as grain residues, provide the main source of insect infestation in stored grain (Cotton et al., 1960). Field infestation is most prevalent in the South, but occurs to some extent even in the northern states (Cotton and Ashby, 1952). Floyd et al. (1959) found standing corn in Louisiana to be heavily damaged by infestation with $S$. oryzae, $S$. 
cerealella, C. quadricollis, $T$. castaneum and $C$. pusillus. Kernel damage by $S$, oryzae averaged about $10 \%$ at harvest and increased during storage. Large numbers of stored-product insects can be found around grain storages throughout the year in southeastern U.S., indicating the possibility of continuing infestation (Throne and Cline, 1989, 1991, 1994).

Understanding and modeling infestation of stored grain thus requires more than data on spatial and temporal dynamics of insect populations living within grain bulks, although such data are indispensable. Measurements of immigration (and emigration) rates are also required, but there have been few studies, such as that reported by Cotton et al. (1960), that provide quantitative data for these processes. Spatial dynamics of insects within stored grain cannot be used without additional information to make inferences regarding mechanisms of infestation, as has sometimes been attempted. Hagstrum (1989), for example, observed that numbers of adult Cryptolestes ferrugineus (Stephens) in newly harvested wheat, summed over the first 2 months of storage, decreased with depth in the grain bulk. From this, he inferred that infestation must occur first at the surface-presumably by immigration from outside the bin-and then spread downward. Our observations do not suggest this pattern, and although Hagstrum's regression model fits his data well for the first 60 days of storage, it lacks general applicability to grain infestation over longer storage periods (Fig. 6). The problem is that any distribution can arise in more than one way. The distribution observed by Hagstrum, for example, also could be explained by upward movement and concentration of insects near the surface immediately after loading lightly infested grain; the negative geotaxis exhibited by stored-product insects when disturbed is well known. Immigration may be the primary mechanism of infestation in some cases, but direct measurements are needed for definitive proof. Also, the contribution of field infestation and passive invasion by pests in harvested grain needs to be assessed. Making inferences about mechanisms in the absence of such data poses the danger of oversimplification in modeling infestation.

The study reported here provides information necessary to develop and validate models of pest population dynamics in one storage habitat, farm-stored maize in South Carolina, but characterization of this habitat is still incomplete. Complete characterization of this, or any storage habitat, requires not only information about the biotic and abiotic environment within the stored grain, but also information on sources and mechanisms of infestation and rates of insect immigration and emigration. The dynamics of field infestation and insect movements between reservoirs of infestation and storages remain largely uninvestigated. Full characterization of various storage habitats is needed to model the diverse conditions that exist in marketing channels and to develop new pest management strategies with minimum reliance on chemical pesticides.

Acknowledgements - We are indebted to R. V. Byrd, M. Carthon, M. P. Culik, J. A. Barron and P. L. Lang for technical assistance. Insect specimens were identified by the following specialists: R. S. Beal, Colorado Christian University; R. W. Carlson, E. E. Grissell, T. J. Henry, J. Pakaluk and J. M. Kingsolver, Systematic Entomology Laboratory, U.S. Department of Agriculture; J. R. Dogger, Beneficial Insects Laboratory, U.S. Department of Agriculture; J. H. Frank, Department of Entomology and Nematology, University of Florida; and M. C. Thomas, Division of Plant Industry, Florida Department of Agriculture and Consumer Services. We thank J. J. Bates, P. K. Green, N. T. McKenzie, H. Peeples, R. Rentz and C. M. Shuman for their cooperation and support of our research on their farms. We thank D. W. Hagstrum, J. D. Sedlacek, D. K. Weaver and J. L. Zettler for their critical review of an earlier version of this paper and for their helpful suggestions.

\section{REFERENCES}

Arbogast R. T. (1991) Identification of Cryptolestes ferrugineus and Cryptolestes pusillus (Coleoptera: Cucujidae): a practical character for sorting large samples by species. Entomological News 102, 33-36.

Arbogast R. T. and Mullen M. A. (1988) Insect succession in a stored-corn ecosystem in Southeast Georgia. Annals of the Entomological Society of America 81, 899-912.

Barak A. V. and Harein P. K. (1981) Insect infestation of farm-stored shelled corn and wheat in Minnesota. Journal of Economic Entomology 74, 197-202.

Bartelt R. J., Weaver D. K. and Arbogast R. T. (1995) Aggregation pheromone of Carpophilus dimidiatus (F.) (Coleoptera: Nitidulidae) and responses to Carpophilus pheromones in South Carolina. Journal of Chemical Ecology 21, $1763-1779$.

Burkholder, W. E. (1984) The use of pheromones and food attractants for monitoring and trapping stored-product insects. In Insect Management for Food Storage and Processing, ed. F. J. Baur, pp. 70-86. American Association of Cereal Chemists, St. Paul, MN.

Calderon M. (1981) The ecosystem approach for apprehending the extent of postharvest grain losses. Phytoparasitica 9 , $157-167$.

Cotton R. T. and Ashby W. (1952) Insect pests of stored grains and seed. In Insects, The 1952 Yearbook of Agriculture, pp. 629-639. U.S. Department of Agriculture, Washington.

Cotton R. T., Walkden H. H., White G. D. and Wilbur D. A. (1960) Causes of outbreaks in stored-grain insects. Bulletin 
No. 416. Agricultural Experiment Station, Kansas State University and U.S. Department of Agriculture cooperating, Manhattan.

Eden W. G. (1967) Insect damage to corn in three southeastern states at time of harvest and in farm storage. Marketing Research Report No. 792. Agricultural Research Service, U.S. Department of Agriculture, Washington.

Floyd E. H., Oliver A. D. and Powell J. D. (1959) Damage to corn in Louisiana caused by stored-grain insects. Journal of Economic Entomology 52, 612-615.

Hagstrum D. W. (1989) Infestation by Cryptolestes ferrugineus (Coleoptera: Cucujidae) of newly harvested wheat stored on three Kansas farms. Journal of Economic Entomology 82, 655-659.

Halstead D. G. H. (1963) The separation of Sitophilus oryzae (L.) and S. zeamais Motschulsky (Col., Curculionidae), with a summary of their distribution. Entomologists' Monthly Magazine 94, 72-74.

Halstead D. G. H. (1993) Keys for the identification of beetles associated with stored products-II. Laemophloeidae, Passandridae and Silvanidae. Journal of Stored Products Research 29, 99-197.

Halstead J. A. (1990) Review of Haltichella Spinola in the Nearctic region (Hymenoptera: Chalcididae). Proceedings of the Entomological Society of Washington 92, 153-159.

Horton P. M. (1981) Identification and control of on-farm stored product insect problems in South Carolina [dissertation]. Auburn (AL): Auburn University. 144 pp. Available from: University Microfilms, Ann Arbor, MI; AAC8120494.

Horton P. M. (1982) Stored product insects collected from on-farm storage in South Carolina. Journal of the Georgia Entomological Society 17, 485-491.

Lefkovitch L. P. (1959) A revision of the European Laemophloeinae (Coleoptera: Cucujidae). Transactions of the Royal Entomological Society of London 111, 95-118.

Linsley E. G. (1944) Natural sources, habitats, and reservoirs of insects associated with stored food products. Hilgardia $16,187-224$.

Scheaffer R. L., Mendenhall W. and Ott L. (1986) Elementary Survey Sampling. Duxbury Press, Boston, MA.

Sinha R. N. (1973) Interrelations of physical, chemical, and biological variables in the deterioration of stored grains. In Grain storage: part of a system, ed. R. N. Sinha and W. E. Muir, pp. 15-47. AVI, Westport, CT.

Sinha R. N. (1995) The stored-grain ecosystem. In Stored-grain Ecosystems, ed. D. S. Jayas, N. D. G. White and W. E. Muir, pp. 1-32. Marcel Dekker, New York.

Storey C. L., Sauer D. B., Ecker O. and Fulk D. W. (1982) Insect infestations in wheat and corn exported from the United States. Journal of Economic Entomology 75, 827-832.

Throne J. E. (1995) Computer modeling of the population dynamics of stored-product pests. In Stored-grain Ecosystems, ed. D. S. Jayas, N. D. G. White and W. E. Muir, pp. 169-195. Marcel Dekker, New York.

Throne J. E. and Cline L. D. (1989) Seasonal flight activity of the maize weevil, Sitophilus zeamais Motschulsky (Coleoptera: Curculionidae), and the rice weevil, S. oryzae (L.), in South Carolina. Journal of Agricultural Entomology 6, $183-192$.

Throne J. E. and Cline L. D. (1991) Seasonal abundance of maize and rice weevils (Coleoptera: Curculionidae) in South Carolina. Journal of Agricultural Entomology 8, 93-100.

Throne J. E. and Cline L. D. (1994) Seasonal flight activity and seasonal abundance of selected stored-product insects around grain storages in South Carolina. Journal of Agricultural Entomology 11, 321-338.

U.S. Department of Agriculture (1986) Stored-grain insects. Agriculture Handbook No. 500. Agricultural Research Service, U.S. Department of Agriculture, Washington.

U.S. Department of Agriculture (1991) Maintaining insect-free farm-stored grain. Agriculture Information Bulletin No. 580. Agricultural Research Service, U.S. Department of Agriculture, Washington.

Weaver D. K. and Throne J. E. (1994) Life history data for Sitotroga cerealella (Olivier) (Lepidoptera: Gelechiidae) in farm-stored corn and the importance of suboptimal environmental conditions in insect population modelling for bulk commodities. In Proceedings of the 6th International Working Conference on Stored-Product Protection, ed. E. Highley, E. J. Wright, H. J. Banks and B. R. Champ, pp. 599-603. Canberra, 1994.

Wong Corral F. J., Cortez Rocha M. O., Borboa Flores J. and Bustamante Andrade F. (1992) Insect species infesting grain stored in rural communities in the northeast of Sonora, Mexico. Southwestern Entomologist 17, 327-331. 